\title{
There are More than Two Sides to Antisocial Behavior: The Inextricable Link between Hemispheric Specialization and Environment
}

\author{
Rotem Leshem 1 \\ Department of Criminology, Bar-Ilan University and Israel, Ramat Gan 5290002, Israel; rotem.leshem@biu.ac.il \\ Received: 16 September 2020; Accepted: 10 October 2020; Published: 13 October 2020 \\ check for \\ updates
}

\begin{abstract}
Human functions and traits are linked to cerebral networks serving different emotional and cognitive control systems, some of which rely on hemispheric specialization and integration to promote adaptive goal-directed behavior. Among the neural systems discussed in this context are those underlying pro- and antisocial behaviors. The diverse functions and traits governing our social behavior have been associated with lateralized neural activity. However, as with other complex behaviors, specific hemispheric roles are difficult to elucidate. This is due largely to environmental and contextual influences, which interact with neural substrates in the development and expression of pro and antisocial functions. This paper will discuss the reciprocal ties between environmental factors and hemispheric functioning in the context of social behavior. Rather than an exhaustive review, the paper will attempt to familiarize readers with the prominent literature and primary questions to encourage further research and in-depth discussion in this field.
\end{abstract}

Keywords: cerebral lateralization; hemispheric asymmetry; antisocial behavior; social environment

\section{Introduction}

The search for neurobiological correlates of adverse social behaviors, such as violence, addiction, and crime, encompasses an ongoing investigation into the role of functional cerebral asymmetry and interhemispheric transfer [1-3]. Adult antisocial behaviors are defined as disruptive behaviors that violate social rules and involve defiance of authority and disregard for the rights of others [4]. They often include rule-breaking, criminal, and violent acts, as well as a failure to follow moral guidelines [5], and have been associated with the pursuit of power and the manipulation and exploitation of others to achieve personal goals [1]. While antisocial behavior is a component in psychiatric disorders, including antisocial personality disorder (APD) and psychopathy, it can also occur on its own [4].

The diverse functions and traits governing both pro and antisocial behavior, from inhibitory control to attention to empathy, have been associated with lateralized neural activity $[1,6]$. However, as with other complex behaviors, specific hemispheric roles are difficult to elucidate [7-9]. This is presumably due in large part to environmental and contextual influences, which interact with neural substrates in the development and expression of pro and antisocial functions [10,11]. The current paper addresses the interdependent roles of hemispheric functioning and environmental factors in the context of antisocial behavior, both to familiarize readers with the prominent literature and primary questions and to encourage further research and in-depth discussion in this field.

\section{Cerebral Asymmetry}

The idea that the two hemispheres operate in different, albeit integrated, ways is the basis for discussing neural lateralization and asymmetry with respect to any particular behavior or ability [12,13]. Lateralization is believed to enable efficient use of brain tissue and increase neural capacity by preventing 
unnecessary duplication, contributing significantly to the brain's plasticity and adaptability in the face of social, environmental, and pathological changes [14-16].

At the most basic level, the left hemisphere (LH) is generally associated with language functions including speech, comprehension, and writing, as well as arithmetic. Meanwhile, the right hemisphere $(\mathrm{RH})$ is said to underlie creativity, visuo-spatial skills, and facial recognition $[12,14,17]$. Beyond this relatively simplistic division, several researchers have attempted to characterize hemispheric and inter-hemispheric activity in greater detail $[8,18]$. The two hemispheres are believed to interpret the same data and organize contextual connections between elements of information in different ways [18-20]. In this view of hemispheric lateralization, the LH is associated with sequential information processing and logical thinking, and it facilitates analysis by organizing symbolic or iconic material to create a strictly ordered and unambiguously understood context [14,21]. The RH, meanwhile, is associated with image thinking and the single-stage parallel processing of many elements of information, creating an integral but ambiguous context [21].

While this and other conceptualizations of cerebral asymmetry highlight different modes of experiencing and responding to the world, it is clear that the two hemispheres are interdependent [22-24]. Under normal circumstances, the brain works as an integrated whole, with the two hemispheres transferring information between them via the corpus callosum to create a unified and coherent experience [1,14]. When the balance between them is disrupted by damage to a particular hemisphere or to the quality of interhemispheric transfer, specific deficits in cognitive and emotional processes can arise $[2,17,25,26]$. In the following section, I present research on lateralized dysfunction in relation to antisocial behaviors, including antisocial personality disorder and psychopathic traits. Later in the paper, I discuss modulation of these brain-behavior relationships by environmental and contextual factors.

\section{Neural and Cognitive Substrates of Antisocial Behavior}

Successful, adaptive social and interpersonal relationships generally involve solidarity, compassion, and consideration for the feelings and needs of another, all of which rely heavily on emotional comprehension and processing abilities [1,27]. Adaptive social behavior also relies on cognitive control and executive functions, including goal-directed behavior, decision-making, and planning [28,29], which support self-regulation and the inhibition of inappropriate behavior [29,30]. When any of the emotional and cognitive functions underlying adaptive social functioning are damaged, antisocial behavior can occur [31-33].

In accordance with the reliance of social functioning on both emotional and cognitive components, antisocial behavior has been associated with damage to brain regions involved in decision-making, inhibitory control, impulsivity, reactive aggression, and dysregulation of emotions [34-36]. These areas converge into two main neural networks (see Figure 1): the cognitive control network, including the lateral prefrontal and parietal cortices and parts of the anterior cingulate cortex (ACC) associated with the cognitive control processes, and the socio-emotional network, which includes the amygdala, ventral striatum, ventromedial prefrontal cortex (VMPFC), orbitofrontal cortex (OFC), and superior temporal sulcus [37,38]. Each of these networks can further be divided into left and right hemisphere components e.g., [39] which are discussed in the context of antisocial behavior below. 


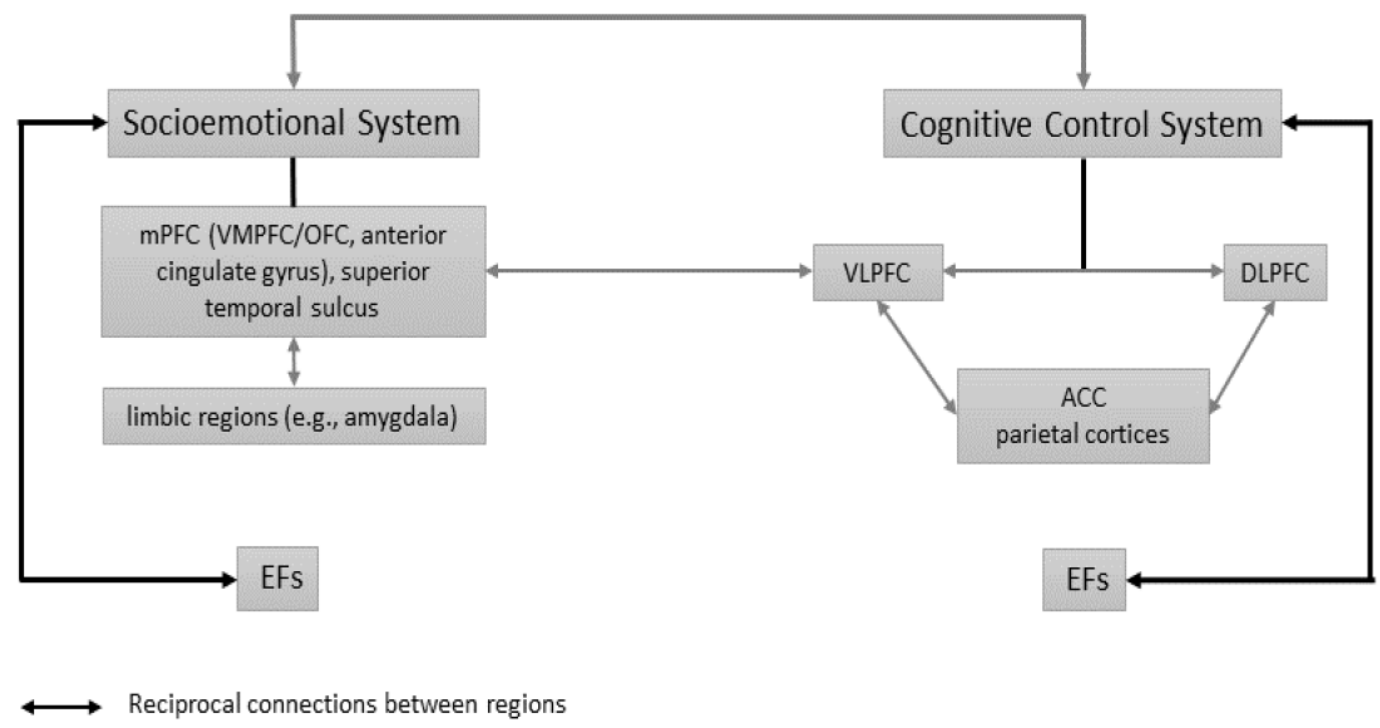

Figure 1. (Adapted from [40]). Representation of the socioemotional and cognitive control systems, which are associated with executive mechanisms related to antisocial behavior. $\mathrm{mPFC}=$ medical prefrontal cortex; $\mathrm{OFC}=$ orbitofrontal cortex; VLPFC = ventrolateral prefrontal cortex; DLPFC = dorsolateral prefrontal cortex; $\mathrm{ACC}=$ anterior cingulate cortex; $\mathrm{EFs}=$ executive functions.

\section{Lateralized Neural and Cognitive Substrates in Antisocial Behavior}

Based on empirical studies of split-brain patients and individuals with head injuries and mental disorders, the diverse functions governing social tendencies and behavior have been associated with lateralized cortical and subcortical neural activity [17,41-45]. These findings have elicited work addressing the roles of lateralized function and damage in antisocial behavior $[26,46,47]$.

There is evidence that anatomical and functional abnormalities in regions including the OFC, dorsolateral prefrontal cortex (DLPFC), ACC, and temporal cortex, as well as subcortical regions result in different antisocial styles when the two hemispheres are differentially affected $[11,26,35,36,48]$. Generally speaking, reduced RH activity appears to be associated with impaired socioemotional and behavioral functioning, such as the inability to withdraw from aversive and dangerous situations, whereas disinhibition and impaired approach behaviors, such as impulsivity, stimulation seeking, and aggression, have been linked primarily to an overactive LH [49-52]. In accordance, there are studies describing antisocial behavior characterized by affective and interpersonal deficits, believed to be mediated by an underactive $\mathrm{RH}$, and antisocial behavior characterized by an impulsive, aggressive, and reward-seeking style, associated with an overactive $\mathrm{LH}[1,5,6,53]$.

Imaging studies do indeed report RH gray matter and white matter fiber reductions, as well as functional changes in regions associated with empathy, recognition of facial emotion, abstract reasoning, and theory of mind, among individuals who exhibit antisocial behaviors [36,54-60]. In a study of individuals with focal, stable unilateral lesions in either the right or left VMPFC, Tranel, Bechara, and Denburg [61] showed that participants with right-sided lesions exhibited profound disturbances in social and interpersonal behavior, emotional processing, and personality, meeting the criteria for acquired sociopathy. In contrast, participants with left-sided lesions tended to exhibit normal social and interpersonal behavior and intact emotional processing.

Other studies report different, and sometimes contradicting patterns associated with LH versus RH dysfunction $[14,36,62]$. In these studies, antisocial behavior has been associated with decreased LH or increased RH activity, as demonstrated in neuroimaging studies. A study by Bertsch et al. [35] reported reduced gray matter volumes in the left postcentral gyrus, left dorsomedial PFC, and right posterior cingulate and precuneus among individuals with antisocial personality disorder with psychopathic traits, as compared with healthy individuals. An additional study [63] found that reduced white 
matter integrity in different regions in both the LH and RH was correlated with impulsivity and risky behaviors in participants with antisocial personality disorder.

Raine et al. [64] examined individuals who had committed predatory murders, which involved well-planned and structured hostility, and affective aggressive murders involving unstructured affective arousal and aggression. They found greater subcortical functioning in the RH and a smaller prefrontal/subcortical ratio in the RH in the affective aggressive murderers. They also reported abnormal subcortical asymmetries, with lower LH than RH metabolic activity in the thalamus, amygdala, and medial temporal lobe. Their findings reflect the role of RH cortical and subcortical pathways in basic emotional processing $[21,65,66]$ and the role of the LH in propositional understanding of emotional information, which enables verbalization that is more informational than experiential. As such, the LH might not be integral to the initial perceptual and experiential stages of emotional processing, but rather attuned to the outcomes of $\mathrm{RH}$ processing and their application to executive functioning, social well-being, and knowledge representation [66].

Based on a meta-analysis of imaging studies, Yang and Raine [67] reported significantly reduced prefrontal structure and function in individuals with antisocial behavior. They found more prominent structural and functional deficits in the $\mathrm{RH}$ than in the $\mathrm{LH}$, showing reductions in the right OFC and right ACC. However, they also reported deficits in the left DLPFC, which is associated with self-regulatory processes such as the allocation and sustaining of attention and cognitive flexibility [68-71]. Other regions of interest with respect to antisocial behavior are the amygdala and hippocampus [72], which have been studied significantly less than the PFC. Existing studies most often report bilateral involvement, although some do report atypical asymmetry [26,73-75].

The large variation in the findings on lateralized neural dysfunction likely reflects heterogeneity among the samples of antisocial individuals with different patterns of cognitive and emotional deficits, as well as diverse behavioral and neuroimaging methodologies [67]. Beyond this, it is clear that neural substrates interact with the environment, which also plays a key role in the development and expression of antisocial tendencies.

\section{Environmental Influences on Neural Substrates and Behavioral Expressions of Antisocial Tendencies}

The roles of external environmental factors on antisocial behavior, within the context of cerebral lateralization, are discussed below with respect to two broadly-defined categories: (1) environmental effects on early and ongoing neural development, contributing to the creation of neural function and dysfunction associated with antisocial behavior, and (2) contextual determinants of antisocial behavior, or aspects of the environment that contribute to the expression of antisocial behaviors.

\subsection{Environmental Effects on Early and Ongoing Development of Lateralized Neural Functions Associated with Antisocial Behavior}

While hemispheric lateralization appears to play an important role in the development of the skills enabling prosocial behavior [14,76], the internal mechanisms and external influences underlying the development of cerebral asymmetries are not clear (see 50 for extensive review). This question is part of the more extensive nature versus nurture discussion, concerning the interplay between heredity and environment in determining behavior. While structural and functional hemispheric asymmetries become established in the human fetus, attesting to genetic underpinnings [39,77], postnatal environments also have lifelong effects on brain health [78]. Indeed, a significant body of work shows that mental states and behavioral outcomes, including antisocial traits and behavior, are a reflection of both environmental experiences and innate factors that impact the brain's ability to adapt to changing environmental demands [79-83].

Postnatal brain development is a heavily experience-dependent period of opportunity and vulnerability [84]. The effects of experience go beyond the simple modulation of plasticity [84-86]. In fact, experience forms and shapes the anatomical and functional structure of the brain [84]. From birth, 
the brain rapidly creates connections between neurons that form our habits, thoughts, consciousness, memories, and mind through repeated experiences and learning $[87,88]$. Increases in the connections between higher-order association areas in the frontal lobes strengthen the ability to exert cognitive and emotional control $[89,90]$, and they are thought to support improvements in executive abilities such as response inhibition, strategic planning, and impulse regulation [40,91].

Positive life experiences and enriched environments are known to foster healthy brain function and behaviors [92]. Meanwhile, adversities, negative life events, and parental variables such as maternal substance abuse and parental deprivation appear to interfere with neurobiological developmental processes [93]. Longitudinal and cross-sectional brain imaging studies have shown that chronic stress, deprivation, and maltreatment in the first years of life are associated with brain volume reductions and significant brain development abnormalities in affected children [10,93].

Brain asymmetries and lateralized functions are also determined by internal and external factors before and in the years immediately following birth [78,88]. Certain areas of the RH develop earlier than the homologous areas of the $\mathrm{LH}$, beginning in utero and continuing at least through the first few years of human life $[76,94,95]$. Brain development appears to begin with a growth spurt of the RH during the first two years of life that is shaped by emotional communications with the caregiver [92]. The RH, which is heavily involved in emotional and social processing, is believed to maintain dominance for the first three years after birth until LH development catches up [92].

Atypical brain asymmetries are believed to be the product of disruptions in these early neurodevelopmental processes $[74,96]$. The resulting alterations in neural circuits have been associated with behavioral phenotypes, including antisocial tendencies, as expressed in delinquency and physical aggression [74,97-100].

The most studied environmental factors among diverse antisocial populations are parenting variables (e.g., neglect, inconsistent parenting), negative life experiences (e.g., sexual abuse, physical abuse, exposure to violence), antisocial culture (e.g., poor neighborhoods), family wealth or economic status, and personal employment [79,98,101-103]. As noted above, these factors are known to play an important role in the development of functional lateralization in cortical and subcortical systems. For example, through its associations with prenatal factors, parent-child interactions, and cognitive stimulation in the home environment, socioeconomic status (SES) appears to have a particular influence on the frontal systems in the LH, including the left inferior frontal gyrus [104,105]. Other studies have focused on the lateralized subcortical systems responsible for survival functions involved in learning, emotions, and memories, such as the hippocampus and amygdala [62,106-109]. Limbic system structures are believed to be more closely connected with the RH cortex [21,92], leading to the suggestion that attachment experiences preferentially affect right brain networks that are critical to regulatory processes and to the ability to adapt to social-emotional environments $[23,92,110]$.

Other environmental factors, such as early stress, exposure to trauma, and substance use have also been associated with abnormal lateralization in subcortical brain regions associated with antisocial tendencies, including the hippocampus [74,111]. While hippocampal structural abnormalities have been linked to antisocial behavior, the nature of this relationship is not yet understood [5,74].

Beyond direct influences on RH and LH development, exposure to stress, neglect, and maltreatment during childhood can result in poor interhemispheric communication due to corpus callosal abnormalities [111,112]. A deprivation or lack of early experience reduces brain stimulation during development, which weakens the growth and development of the corpus callosum and thereby disrupts hemispheric specialization $[113,114]$. Reduced communication between the cortical and subcortical regions in the two hemispheres can potentially play a causal role in the affective and cognitive deficits that characterize individuals with antisocial behavior [2,26] (see Figure 2). 


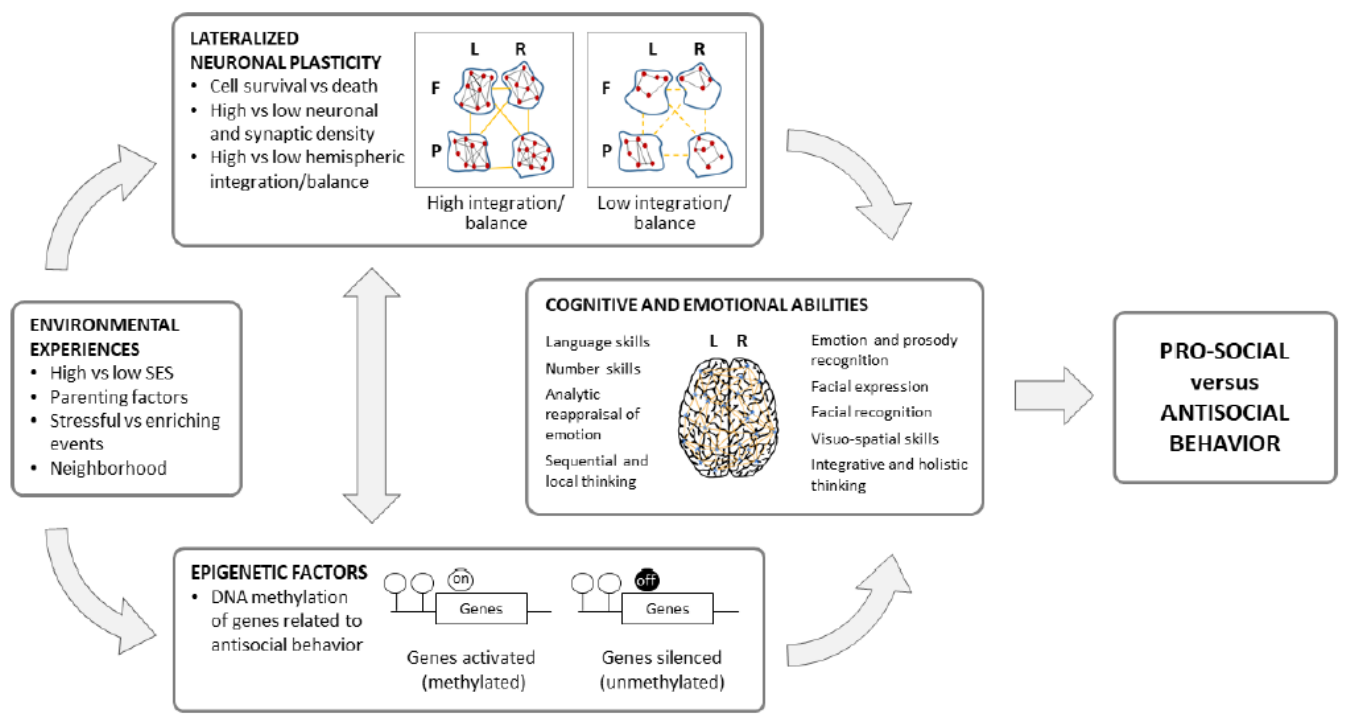

Figure 2. The interplay between environmental, epigenetic, and neural influences on the cognitive and emotional abilities underlying pro- and anti-social behavior. Life experiences and diverse environments affect connections between higher-order association areas in the frontal and parietal lobes in the left (L) and right $(\mathrm{R})$ hemispheres, as well as DNA methylation-dependent gene expression. These interrelated mechanisms, in turn, affect lateralized emotional and cognitive abilities related to antisocial behavior.

The Role of Epigenetic Factors in the Development of Neural Asymmetry and Antisocial Behavior

Due to their role in the development of hemispheric asymmetries, epigenetic mechanisms, which are tied to the environment for extensive review see [39], can also affect antisocial behavior. A primary epigenetic mechanism is DNA methylation (DNAm), a covalent modification of the DNA molecule that serves as an interface between the dynamic environment and the fixed genome $[115,116]$. Unlike the DNA sequence, which is stable and robust, epigenetic processes are often tissue-specific, developmentally regulated, and highly dynamic [116]. The epigenetic control of biological pathways within the neuroendocrine, serotonergic, and oxytocinergic systems plays a crucial role in the cognitive and emotional processes underlying social behavior [117-121]. DNAm is also linked to the lateralization of nervous system organization, which is among the mechanisms through which it can contribute to antisocial behavior and related psychopathic traits

Indeed, epigenetic mechanisms might underlie relationships between environmental factors and antisocial tendencies (see Figure 2) [10,122]. Criminology research examining early life adversity, from socioeconomic conditions to family environment to trauma, shows that life experiences can result in stable changes in DNAm $[81,82,123,124]$. Tobacco exposure, substance use, and psychosocial stress are among the few established environmental sources of methylation change related to antisocial behavior $[125,126]$. Given these recent findings, further research is needed to better understand the ontogenesis of functional lateralization at the population and individual levels, particularly with respect to antisocial behavior.

\subsection{Environmental and Contextual Determinants of Antisocial Behavior}

Environmental factors not only influence the development of lateralized dysfunctions underlying antisocial tendencies, but also influence the expression of these tendencies $[127,128]$. While the neural factors described above appear to predispose individuals to antisocial behavior, the deficits manifested in a given situation also depend on situational demands and stimulus types, which can differentially activate different regions in one or both hemispheres (see Figure 3) $[66,129,130]$. 
(A)

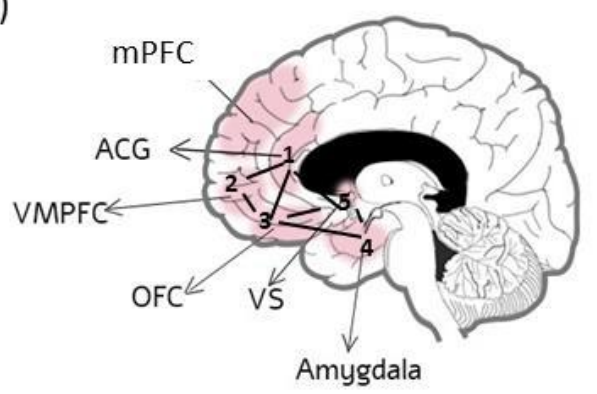

(B)

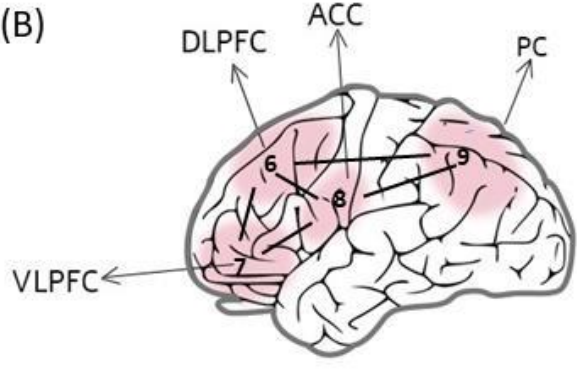

Figure 3. Brain areas associated with performance of tasks with predominantly emotional (A) versus cognitive (B) stimulus types. Stimulus types as well as situational demands (e.g., high/low cognitive load) can activate different regions in the socioemotional and cognitive control networks in one or both hemispheres. Depending on these and other contextual factors, deficits in these neural circuits can lead to the expression of different antisocial behaviors.

In healthy individuals, different stimulus characteristics are known to be associated with different neural patterns during cognitive and emotional task performance [131-133]. Nejati et al. [28], for example, investigated how the left DLPFC (l-DLPFC) and right OFC ( $\mathrm{r}-\mathrm{OFC}$ ) interact in healthy participants during affective and cognitive executive functioning, using several behavioral tasks and transcranial direct current stimulation (tDCS). They found that the affective components of executive functioning, which they defined as risk-taking behavior and risky decision-making, required involvement of both the r-OFC and the l-DLPFC, while the cognitive components of inhibitory control and planning relied more exclusively on l-DLPFC activity. Their findings reflect the differential recruitment of the l-DLPFC and r-OFC based on the degree of involvement of cognitive control and emotional-motivational processes in a given task, and they support the possibility that impairments in these regions result in different behavioral outcomes, based on the task at hand.

Accordingly, individuals with deficits in the l-DLPFC might exhibit antisocial behavior in situations involving sudden changes in environmental constraints or internal goals, which require the suppression of irrelevant information and resolution of conflict between competing demands $[5,134,135]$. In contrast, individuals with deficits in the r-OFC might exhibit antisocial behavior in situations that require resisting temptation or rewards associated with risky and negative outcomes $[5,136,137]$. Thus, abnormal functioning in these regions will not necessarily result in antisocial behavior, but rather create antisocial tendencies that manifest differently depending on external stimuli and demands.

A model that directly addresses dynamic cerebral asymmetry in antisocial behavior is the LH Activation (LHA) hypothesis [138], which largely attributes psychopathy to LH dysfunction. Specifically, the LHA hypothesis predicts that information processing is disrupted among individuals with psychopathic tendencies when LH resources are substantially and differentially activated by processing demands [139]. Cognitive deficits in individuals with psychopathic traits are therefore viewed as state-specific, or evident only under conditions that require the substantial involvement of LH resources $[139,140]$. This model can explain inconsistent findings among individuals with psychopathic traits in performing tasks that pose different cognitive demands $[139,140]$. It is also in line with the behavioral variability often exhibited by this population, which can be controlled and restrained at times, and at other times exhibits poor judgment, outbursts of rage, and poor moral judgment [139]. The LHA hypothesis is supported by imaging and behavioral studies showing LH involvement in cognitive strategy use, such as the reappraisal and regulation of emotion $[25,141,142]$.

\section{Implications and Conclusions}

The ideas and findings described above highlight the integrative roles of lateralized neural function and environmental influences in the creation and expression of antisocial tendencies (e.g., [26,143]). A primary implication of environmental influences on the expression of antisocial behavior in 
biologically predisposed individuals is the possibility that we can control and decrease these expressions through interventions $[144,145]$. Just as external environmental effects on lateralized neurobiological mechanisms can lead to the expression of antisocial tendencies, the environment (i.e., exposure to an enriched environment) can reduce antisocial behaviors and facilitate prosocial behaviors $[120,146]$.

Beyond the removal or alteration of environmental triggers, environmental conditions can affect the brain, making an individual less susceptible to neural deficits resulting in antisocial behavior $[79,81,147]$. In the context of lateralization, various techniques are believed to influence brain organization, improving functions associated with each of the hemispheres and strengthening communication between them [148]. For example, strengthening language skills can activate neural language circuits in the LH that are closely related to areas responsible for goal-directed behavior and cognitive control $[149,150]$. Stronger LH functions can also facilitate RH functions, such as by providing interpretation and reappraisal of emotions processed in the RH [66]. Recently, a sensorimotor training program has been shown to increase intra- and inter-hemispheric functional connectivity, which in turn improves cognitive and emotional functions (for details, see $[25,106])$. Further research is needed to examine the effectiveness of this type of intervention in addressing antisocial behavior.

At the broader societal level, it appears that certain social environments, such as those associated with greater exposure to crime, produce more frequent triggers for antisocial behavior [102,151]. Sociocultural factors, like an emphasis on individualism versus collectivism, can also affect the extent to which antisocial tendencies will be expressed [152], even when an individual is predisposed to such tendencies due to specific neural patterns of cognitive and emotional dysfunction [153]. Further research is required to examine this issue in depth.

In conclusion, in discussing the roles of the environment and lateralized neurobiology in antisocial behavior, it is clear that the whole is more than the sum of its parts. Due to the magnitude and complexity of nature-nurture interactions, studies focusing on only one of these components cannot truly elucidate the causes and foundations of antisocial behavior. Though references are made in the literature to an antisocial brain or antisocial hemisphere, it is highly unlikely that any structural or functional neural pattern can be unequivocally associated with antisocial behavior [154]. Likewise, while certain environmental factors have been clearly associated with antisocial behavior, none will categorically cause all exposed individuals to behave antisocially [155]. To better understand why and when antisocial behaviors occur, further multidisciplinary research should specifically address the ties between the neural patterns and environmental influences associated with social functioning.

Funding: This research received no external funding.

Conflicts of Interest: The authors declare no conflict of interest.

\section{Abbreviations}

$\begin{array}{ll}\text { ACC } & \text { anterior cingulate cortex } \\ \text { ACG } & \text { anterior cingulate gyrus } \\ \text { APD } & \text { antisocial personality disorder } \\ \text { DLPFC } & \text { dorsolateral prefrontal cortex } \\ \text { DNAm } & \text { DNA methylation } \\ \text { 1-DLPFC } & \text { left DLPFC } \\ \text { LH } & \text { left hemisphere } \\ \text { mPFC } & \text { medial prefrontal cortex } \\ \text { OFC } & \text { orbitofrontal cortex } \\ \text { PC } & \text { parietal cortex } \\ \text { PFC } & \text { prefrontal cortex } \\ \text { r-OFC } & \text { right OFC } \\ \text { RH } & \text { right hemisphere } \\ \text { SES } & \text { socioeconomic status }\end{array}$


tDCS transcranial direct current stimulation

VLPFC ventrolateral prefrontal cortex

VMPFC ventromedial prefrontal cortex

vs. ventral striatum

\section{References}

1. Hecht, D. Cerebral lateralization of pro-and anti-social tendencies. Exp. Neurobiol. 2014, 23, 1-27. [CrossRef] [PubMed]

2. Raine, A.; Lencz, T.; Taylor, K.; Hellige, J.B.; Bihrle, S.; Lacasse, L.; Lee, M.; Ishikawa, S.; Colletti, P. Corpus callosum abnormalities in psychopathic antisocial individuals. Arch. Gen. Psychiatry 2003, 60, 1134-1142. [CrossRef] [PubMed]

3. Ward, T.; Wilshire, C.; Jackson, L. The contribution of neuroscience to forensic explanation. Psychol. Crime Law 2018, 24, 195-209. [CrossRef]

4. American Psychiatric Association. Diagnostic and Statistical Manual of Mental Disorders (DSM-5 $\left.{ }^{\circledR}\right)$; American Psychiatric Publishing: Philadelphia, PA, USA, 2013.

5. Raine, A.; Yang, Y. Neural foundations to moral reasoning and antisocial behavior. Soc. Cogn. Affect. Neurosci. 2006, 1, 203-213. [CrossRef]

6. Hecht, D. An inter-hemispheric imbalance in the psychopath's brain. Personal. Individ. Differ. 2011, 51, 3-10. [CrossRef]

7. Chen, C.; Omiya, Y. Brain asymmetry in cortical thickness is correlated with cognitive function. Front. Hum. Neurosci. 2014, 8, 877. [CrossRef]

8. Karolis, V.R.; Corbetta, M.; De Schotten, M.T. The architecture of functional lateralisation and its relationship to callosal connectivity in the human brain. Nat. Commun. 2019, 10,1-9. [CrossRef] [PubMed]

9. Kong, X.Z.; Mathias, S.R.; Guadalupe, T.; Glahn, D.C.; Franke, B.; Crivello, F.; Tzourio-Mazoyer, N.; Fisher, S.E.; Thompson, P.M.; Francks, C.; et al. Mapping cortical brain asymmetry in 17,141 healthy individuals. Studies 2014, 40, E5154-E5163.

10. Frazier, A.; Ferreira, P.A.; Gonzales, J.E. Born this way? A review of neurobiological and environmental evidence for the etiology of psychopathy. Personal. Neurosci. 2019, 2, e8. [CrossRef]

11. Reddy, K.J.; Menon, K.R.; Hunjan, U.G. Neurobiological Aspects of Violent and Criminal Behaviour: Deficits in Frontal Lobe Function and Neurotransmitters. Int. J. Crim. Justice Sci. 2018, 13, 44.

12. Corballis, M.C.; Häberling, I.S. The many sides of hemispheric asymmetry: A selective review and outlook. J. Int. Neuropsychol. Soc. 2017, 23, 710. [CrossRef] [PubMed]

13. Gotts, S.J.; Jo, H.J.; Wallace, G.L.; Saad, Z.S.; Cox, R.W.; Martin, A. Two distinct forms of functional lateralization in the human brain. Proc. Natl. Acad. Sci. USA 2013, 110, 3435-3444. [CrossRef] [PubMed]

14. Gonzalez, C.L.; van Rootselaar, N.A.; Gibb, R.L. Sensorimotor Lateralization Scaffolds Cognitive Specialization. In Progress in Brain Research; Elsevier: Amsterdam, The Netherlands, 2018; Volume 238, pp. 405-433.

15. Herbet, G.; Duffau, H. Revisiting the functional anatomy of the human brain: Toward a meta-networking theory of cerebral functions. Physiol. Rev. 2020, 100, 1181-1228. [CrossRef] [PubMed]

16. Vallortigara, G.; Rogers, L. Survival with an asymmetrical brain: Advantages and disadvantages of cerebral lateralization. Behav. Brain Sci. 2005, 28, 575-633. [CrossRef] [PubMed]

17. Gazzaniga, M.S. Cerebral specialization and interhemispheric communication: Does the corpus callosum enable the human condition? Brain 2000, 123, 1293-1326. [CrossRef]

18. O'Regan, L.; Serrien, D.J. Individual differences and hemispheric asymmetries for language and spatial attention. Front. Hum. Neurosci. 2018, 12, 380. [CrossRef] [PubMed]

19. Badzakova-Trajkov, G.; Häberling, I.S.; Roberts, R.P.; Corballis, M.C. Cerebral asymmetries: Complementary and independent processes. PLoS ONE 2010, 5, e9682. [CrossRef]

20. Hervé, P.Y.; Zago, L.; Petit, L.; Mazoyer, B.; Tzourio-Mazoyer, N. Revisiting human hemispheric specialization with neuroimaging. Trends Cogn. Sci. 2013, 17, 69-80. [PubMed]

21. Rotenberg, V.S.; Weinberg, I. Human memory, cerebral hemispheres, and the limbic system: A new approach. Genet. Soc. Gen. Psychol. Monogr. 1999, 125, 45-70. 
22. Corballis, M.C. Humanity and the left hemisphere: The story of half a brain. Laterality 2020, 1-15. [CrossRef] [PubMed]

23. Forrester, G.S.; Todd, B.K. A comparative perspective on lateral biases and social behavior. In Progress in Brain Research; Forrester, G.S., Hopkins, W.D., Hudry, K., Lindell, A., Eds.; Elsevier: Amsterdam, The Netherlands, 2018; Volume 238, pp. 377-403.

24. Ocklenburg, S.; Gunturkun, O. Hemispheric asymmetries: The comparative view. Front. Psychol. $2012,3,5$. [CrossRef] [PubMed]

25. Ochsner, K.N.; Silvers, J.A.; Buhle, J.T. Functional imaging studies of emotion regulation: A synthetic review and evolving model of the cognitive control of emotion. Ann. N. Y. Acad. Sci. 2012, 1251, e1. [CrossRef] [PubMed]

26. Savopoulos, P.; Lindell, A.K. Born criminal? Differences in structural, functional and behavioural lateralization between criminals and noncriminals. Laterality Asymmetries Body Brain Cogn. 2018, 23, 738-760. [CrossRef] [PubMed]

27. Kotz, S.A.; Paulmann, S. Emotion, Language, and the Brain: Emotional Speech and Language Comprehension. Lang. Linguist. Compass 2011, 5, 108-125. [CrossRef]

28. Nejati, V.; Salehinejad, M.A.; Nitsche, M.A. Interaction of the left dorsolateral prefrontal cortex (l-DLPFC) and right orbitofrontal cortex (OFC) in hot and cold executive functions: Evidence from transcranial direct current stimulation (tDCS). Neuroscience 2018, 369, 109-123. [CrossRef] [PubMed]

29. Nigg, J.T. Annual Research Review: On the relations among self-regulation, self-control, executive functioning, effortful control, cognitive control, impulsivity, risk-taking, and inhibition for developmental psychopathology. J. Child Psychol. Psychiatry 2017, 58, 361-383. [CrossRef]

30. Barkley, R.A. The executive functions and self-regulation: An evolutionary neuropsychological perspective. Neuropsychol. Rev. 2001, 11, 1-29. [CrossRef]

31. Brazil, I.A.; van Dongen, J.D.; Maes, J.H.; Mars, R.B.; Baskin-Sommers, A.R. Classification and treatment of antisocial individuals: From behavior to biocognition. Neurosci. Biobehav. Rev. 2018, 91, 259-277. [CrossRef]

32. Hofhansel, L.; Weidler, C.; Votinov, M.; Clemens, B.; Raine, A.; Habel, U. Morphology of the criminal brain: Gray matter reductions are linked to antisocial behavior in offenders. Brain Struct. Funct. 2020, 1-12. [CrossRef]

33. Séguin, J.R. Neurocognitive elements of antisocial behavior: Relevance of an orbitofrontal cortex account. Brain Cogn. 2004, 55, 185-197. [CrossRef]

34. Bertsch, K.; Grothe, M.; Prehn, K.; Vohs, K.; Berger, C.; Hauenstein, K.; Keiper, P.; Domes, J.; Teipel, S.; Herpertz, S.C. Brain volumes differ between diagnostic groups of violent criminal offenders. Eur. Arch. Psychiatry Clin. Neurosci. 2013, 263, 593-606. [CrossRef] [PubMed]

35. Scott, E.S.; Steinberg, L. Adolescent development and the regulation of youth crime. Future Child. 2008, 18, 15-33. [CrossRef] [PubMed]

36. Van der Gronde, T.; Kempes, M.; van El, C.; Rinne, T.; Pieters, T. Neurobiological correlates in forensic assessment: A systematic review. PLoS ONE 2014, 9, e110672. [CrossRef] [PubMed]

37. Shulman, E.P.; Smith, A.R.; Silva, K.; Icenogle, G.; Duell, N.; Chein, J.; Steinberg, L. The dual systems model: Review, reappraisal, and reaffirmation. Dev. Cogn. Neurosci. 2016, 17, 103-117. [CrossRef]

38. Steinberg, L. A social neuroscience perspective on adolescent risk-taking. Dev. Rev. 2008, 28, 78-106. [CrossRef]

39. Schmitz, J.; Güntürkün, O.; Ocklenburg, S. Building an asymmetrical brain: The molecular perspective. Front. Psychol. 2019, 10, 982. [CrossRef]

40. Leshem, R. Using dual process models to examine impulsivity throughout neural maturation. Dev. Neuropsychol. 2016, 41, 125-143. [CrossRef]

41. Corballis, M.C. Evolution of cerebral asymmetry. In Progress in Brain Research; Elsevier: Amsterdam, The Netherlands, 2019; Volume 250, pp. 153-178.

42. Corbetta, M.; Siegel, J.S.; Shulman, G.L. On the low dimensionality of behavioral deficits and alterations of brain network connectivity after focal injury. Cortex 2018, 107, 229-237. [CrossRef]

43. Funk, C.M.; Gazzaniga, M.S. The functional brain architecture of human morality. Curr. Opin. Neurobiol. 2009, 19, 678-681. [CrossRef]

44. Gazzaniga, M.S. Principles of human brain organization derived from split-brain studies. Neuron 1995, 14, 217-228. [CrossRef] 
45. Stiles, J. The effects of early focal brain injury on lateralization of cognitive function. Curr. Dir. Psychol. Sci. 1998, 7, 21-26. [CrossRef]

46. Konikkou, K.; Kostantinou, N.; Fanti, K.A. Transcranial magnetic stimulation over the dorsolateral prefrontal cortex affects emotional processing: Accounting for individual differences in antisocial behavior. J. Exp. Criminol. 2020, 16, 349-366. [CrossRef]

47. Yang, Y.; Raine, A. The neuroanatomical bases of psychopathy: A review of brain imaging findings. In Handbook of Psychopathy; Patrick, C.J., Ed.; The Guilford Press: New York, NY, USA, 2018; pp. 380-400.

48. Pridmore, S.; Chambers, A.; McArthur, M. Neuroimaging in psychopathy. Aust. N. Z. J. Psychiatry 2005, 39, 856-865. [CrossRef] [PubMed]

49. Alves, N.T.; Fukusima, S.S.; Aznar-Casanova, J.A. Models of brain asymmetry in emotional processing. Psychol. Neurosci. 2008, 1, 63.

50. Coan, J.A.; Allen, J.J. Frontal EEG asymmetry and the behavioral activation and inhibition systems. Psychophysiology 2003, 40, 106-114. [CrossRef] [PubMed]

51. Fetterman, A.K.; Ode, S.; Robinson, M.D. For which side the bell tolls: The laterality of approach-avoidance associative networks. Motiv. Emot. 2013, 37,33-38. [CrossRef]

52. Li, C.S.R.; Chao, H.H.A.; Lee, T.W. Neural correlates of speeded as compared with delayed responses in a stop signal task: An indirect analog of risk taking and association with an anxiety trait. Cereb. Cortex 2009, 19, 839-848. [CrossRef]

53. Raine, A.; Park, S.; Lencz, T.; Bihrle, S.; LaCasse, L.; Widom, C.S.; Al-Dayeh, L.; Singh, M. Reduced right hemisphere activation in severely abused violent offenders during a working memory task: An fMRI study. Aggress. Behav. Off. J. Int. Soc. Res. Aggress. 2001, 27, 111-129. [CrossRef]

54. Boes, A.D.; Bechara, A.; Tranel, D.; Anderson, S.W.; Richman, L.; Nopoulos, P. Right ventromedial prefrontal cortex: A neuroanatomical correlate of impulse control in boys. Soc. Cogn. Affect. Neurosci. 2009, 4, 1-9. [CrossRef]

55. Boes, A.D.; Tranel, D.; Anderson, S.W.; Nopoulos, P. Right anterior cingulate: A neuroanatomical correlate of aggression and defiance in boys. Behav. Neurosci. 2008, 122, 677. [CrossRef]

56. Craig, M.C.; Catani, M.; Deeley, Q.; Latham, R.; Daly, E.; Kanaan, R.; Murphy, D.G. Altered connections on the road to psychopathy. Mol. Psychiatry 2009, 14, 946-953. [CrossRef] [PubMed]

57. Kiehl, K.A.; Smith, A.M.; Mendrek, A.; Forster, B.B.; Hare, R.D.; Liddle, P.F. Temporal lobe abnormalities in semantic processing by criminal psychopaths as revealed by functional magnetic resonance imaging. Psychiatry Res. Neuroimaging 2004, 130, 27-42. [CrossRef]

58. Müller, J.L.; Gänßbauer, S.; Sommer, M.; Döhnel, K.; Weber, T.; Schmidt-Wilcke, T.; Hajak, G. Gray matter changes in right superior temporal gyrus in criminal psychopaths. Evidence from voxel-based morphometry. Psychiatry Res. Neuroimaging 2008, 163, 213-222. [CrossRef] [PubMed]

59. Raine, A.; Lencz, T.; Bihrle, S.; LaCasse, L.; Colletti, P. Reduced prefrontal gray matter volume and reduced autonomic activity in antisocial personality disorder. Arch. Gen. Psychiatry 2000, 57, 119-127. [CrossRef] [PubMed]

60. Yang, Y.; Raine, A.; Colletti, P.; Toga, A.W.; Narr, K.L. Abnormal temporal and prefrontal cortical gray matter thinning in psychopaths. Mol. Psychiatry 2009, 14, 561-562. [CrossRef] [PubMed]

61. Tranel, D.; Bechara, A.; Denburg, N.L. Asymmetric functional roles of right and left ventromedial prefrontal cortices in social conduct, decision-making, and emotional processing. Cortex 2002, 38, 589-612. [CrossRef]

62. Dutton, D.G. The neurobiology of abandonment homicide. Aggress. Violent Behav. 2002, 7, 407-421. [CrossRef]

63. Jiang, W.; Shi, F.; Liu, H.; Li, G.; Ding, Z.; Shen, H.; Shen, C.; Lee, S.W.; Hu, D.; Wang, W.; et al. Reduced white matter integrity in antisocial personality disorder: A diffusion tensor imaging study. Sci. Rep. 2017, 7, 43002. [CrossRef]

64. Raine, A.; Meloy, J.R.; Bihrle, S.; Stoddard, J.; Lacasse, L.; Buchsbaum, M.S. Reduced prefrontal and increased subcortical brain functioning assessed using positron emission tomography in predatory and affective murderers. Behav. Sci. Law 1998, 16, 319-332. [CrossRef]

65. Demaree, H.A.; Everhart, D.E.; Youngstrom, E.A.; Harrison, D.W. Brain lateralization of emotional processing: Historical roots and a future incorporating "dominance". Behav. Cogn. Neurosci. Rev. 2005, 4, 3-20. [CrossRef]

66. Shobe, E.R. Independent and collaborative contributions of the cerebral hemispheres to emotional processing. Front. Hum. Neurosci. 2014, 8, 230. [CrossRef] [PubMed] 
67. Yang, Y.; Raine, A. Prefrontal structural and functional brain imaging findings in antisocial, violent, and psychopathic individuals: A meta-analysis. Psychiatry Res. Neuroimaging 2009, 174, 81-88. [CrossRef] [PubMed]

68. Heeren, A.; Baeken, C.; Vanderhasselt, M.A.; Philippot, P.; De Raedt, R. Impact of anodal and cathodal transcranial direct current stimulation over the left dorsolateral prefrontal cortex during attention bias modification: An eye-tracking study. PLoS ONE 2015, 10, e0124182. [CrossRef] [PubMed]

69. Li, Y.; Grabell, A.S.; Wakschlag, L.S.; Huppert, T.J.; Perlman, S.B. The neural substrates of cognitive flexibility are related to individual differences in preschool irritability: A fNIRS investigation. Dev. Cogn. Neurosci. 2017, 25, 138-144. [CrossRef] [PubMed]

70. Luks, T.L.; Simpson, G.V.; Dale, C.L.; Hough, M.G. Preparatory allocation of attention and adjustments in conflict processing. Neuroimage 2007, 35, 949-958. [CrossRef]

71. Wiegand, A.; Sommer, A.; Nieratschker, V.; Plewnia, C. Improvement of cognitive control and stabilization of affect by prefrontal transcranial direct current stimulation (tDCS). Sci. Rep. 2019, 9, 1-8. [CrossRef]

72. Yang, Y.; Glenn, A.L.; Raine, A. Brain abnormalities in antisocial individuals: Implications for the law. Behav. Sci. Law 2008, 26, 65-83. [CrossRef]

73. Kaya, S.; Yildirim, H.; Atmaca, M. Reduced hippocampus and amygdala volumes in antisocial personality disorder. J. Clin. Neurosci. 2020, 75, 199-203. [CrossRef]

74. Raine, A.; Ishikawa, S.S.; Arce, E.; Lencz, T.; Knuth, K.H.; Bihrle, S.; LaCasse, L.; Colletti, P. Hippocampal structural asymmetry in unsuccessful psychopaths. Biol. Psychiatry 2004, 55, 185-191. [CrossRef]

75. Yang, Y.; Raine, A.; Narr, K.L.; Colletti, P.; Toga, A.W. Localization of deformations within the amygdala in individuals with psychopathy. Arch. Gen. Psychiatry 2009, 66, 986-994. [CrossRef]

76. Vallesi, A. Organisation of executive functions: Hemispheric asymmetries. J. Cogn. Psychol. 2012, 24, 367-386. [CrossRef]

77. Kasprian, G.; Langs, G.; Brugger, P.C.; Bittner, M.; Weber, M.; Arantes, M.; Prayer, D. The prenatal origin of hemispheric asymmetry: An in utero neuroimaging study. Cereb. Cortex 2011, 21, 1076-1083. [CrossRef] [PubMed]

78. Vasung, L.; Turk, E.A.; Ferradal, S.L.; Sutin, J.; Stout, J.N.; Ahtam, B.; Lin, P.; Grant, P.E. Exploring early human brain development with structural and physiological neuroimaging. Neuroimage 2019, 187, $226-254$. [CrossRef] [PubMed]

79. Glenn, A.L.; Raine, A. Neurocriminology: Implications for the punishment, prediction and prevention of criminal behaviour. Nat. Rev. Neurosci. 2014, 15, 54-63. [CrossRef] [PubMed]

80. Tremblay, R.E. Developmental origins of disruptive behaviour problems: The 'original sin' hypothesis, epigenetics and their consequences for prevention. J. Child Psychol. Psychiatry 2010, 51, 341-367. [CrossRef]

81. Tremblay, R.E. Developmental origins of chronic physical aggression: An international perspective on using singletons, twins and epigenetics. Eur. J. Criminol. 2015, 12, 551-561. [CrossRef]

82. Tremblay, R.E.; Vitaro, F.; Côté, S. Developmental origins of chronic physical aggression: A bio-psycho-social model for the next generation of preventive interventions. Annu. Rev. Psychol. 2018, 69, 383-407. [CrossRef]

83. Tuvblad, C.; Beaver, K.M. Genetic and environmental influences on antisocial behavior. J. Crim. Justice 2013, 41, 273-276. [CrossRef]

84. Tierney, A.L.; Nelson, C.A., III. Brain development and the role of experience in the early years. Zero Three 2009, 30, 9 .

85. Brzosko, Z.; Mierau, S.B.; Paulsen, O. Neuromodulation of Spike-Timing-Dependent plasticity: Past, present, and future. Neuron 2019, 103, 563-581. [CrossRef]

86. Davidson, R.J.; McEwen, B.S. Social influences on neuroplasticity: Stress and interventions to promote well-being. Nat. Neurosci. 2012, 15, 689-695. [CrossRef] [PubMed]

87. Brenhouse, H.C.; Andersen, S.L. Developmental trajectories during adolescence in males and females: A cross-species understanding of underlying brain changes. Neurosci. Biobehav. Rev. 2011, 35, 1687-1703. [CrossRef] [PubMed]

88. Stiles, J.; Jernigan, T.L. The basics of brain development. Neuropsychol. Rev. 2010, 20, 327-348. [CrossRef] [PubMed]

89. De Fano, A.; Leshem, R.; Ben-Soussan, T.D. Creating an internal environment of cognitive and psycho-emotional well-being through an external movement-based environment: An overview of Quadrato Motor Training. Int. J. Environ. Res. Public Health 2019, 16, 2160. [CrossRef] 
90. Miyake, A.; Friedman, N.P.; Emerson, M.J.; Witzki, A.H.; Howerter, A.; Wager, T.D. The unity and diversity of executive functions and their contributions to complex "frontal lobe" tasks: A latent variable analysis. Cogn. Psychol. 2000, 41, 49-100. [CrossRef]

91. Leshem, R. Brain development, impulsivity, risky decision making, and cognitive control: Integrating cognitive and socioemotional processes during adolescence-An introduction to the special Issue. Dev. Neuropsychol. 2016, 41, 1-5. [CrossRef]

92. Schore, A.N. Attachment, affect regulation, and the developing right brain: Linking developmental neuroscience to pediatrics. Pediatrics Rev. 2005, 26, 204-217. [CrossRef]

93. Bick, J.; Nelson, C.A. Early adverse experiences and the developing brain. Neuropsychopharmacology 2016, 41, 177-196. [CrossRef]

94. Chiron, C.; Jambaque, I.; Nabbout, R.; Lounes, R.; Syrota, A.; Dulac, O. The right brain hemisphere is dominant in human infants. Brain J. Neurol. 1997, 120, 1057-1065. [CrossRef]

95. Kinsbourne, M. Development of Cerebral Lateralization in Children. In Handbook of Clinical Child Neuropsychology; Reynolds, C.R., Fletcher-Janzen, E., Eds.; Springer: New York, NY, USA, 2009; pp. 47-66.

96. Gao, Y.; Glenn, A.L.; Schug, R.A.; Yang, Y.; Raine, A. The Neurobiology of psychopathy: A neurodevelopmental perspective. Can. J. Psychiatry 2009, 54, 813-823. [CrossRef]

97. Blair, R.J.R.; Peschardt, K.S.; Budhani, S.; Mitchell DG, V.; Pine, D.S. The development of psychopathy. J. Child Psychol. Psychiatry 2006, 47, 262-276. [CrossRef] [PubMed]

98. Leshem, R.; Weisburd, D. Epigenetics and hot spots of crime: Rethinking the relationship between genetics and criminal behavior. J. Contemp. Crim. Justice 2019, 35, 186-204. [CrossRef]

99. McAdams, T.A.; Gregory, A.M.; Eley, T.C. Genes of experience: Explaining the heritability of putative environmental variables through their association with behavioural and emotional traits. Behav. Genet. 2013, 43, 314-328. [CrossRef] [PubMed]

100. Seidel, K.; Poeggel, G.; Holetschka, R.; Helmeke, C.; Braun, K. Paternal deprivation affects the development of corticotrophin-releasing factor-expressing neurones in prefrontal cortex, amygdala and hippocampus of the biparental Octodon degus. J. Neuroendocrinol. 2011, 23, 1166-1176. [CrossRef] [PubMed]

101. Baker, L.A.; Bezdjian, S.; Raine, A. Behavioral genetics: The science of antisocial behavior. Law Contemp. Probl. 2006, 69,7 .

102. Blair, R.J.R. The neurobiology of psychopathic traits in youths. Nat. Rev. Neurosci. 2013, 14, 786-799. [CrossRef]

103. Carlisi, C.O.; Moffitt, T.E.; Knodt, A.R.; Harrington, H.; Ireland, D.; Melzer, T.R.; Poulton, R.; Ramrakha, S.; Caspi, A.; Viding, E. Associations between life-course-persistent antisocial behaviour and brain structure in a population-representative longitudinal birth cohort. Lancet Psychiatry 2020, 7, 245-253. [CrossRef]

104. Hackman, D.A.; Farah, M.J.; Meaney, M.J. Socioeconomic status and the brain: Mechanistic insights from human and animal research. Nat. Rev. Neurosci. 2010, 11, 651-659. [CrossRef]

105. Raizada, R.D.; Richards, T.L.; Meltzoff, A.; Kuhl, P.K. Socioeconomic status predicts hemispheric specialisation of the left inferior frontal gyrus in young children. Neuroimage 2008, 40, 1392-1401. [CrossRef]

106. Boles, D.B. Socioeconomic status, a forgotten variable in lateralization development. Brain Cogn. 2011, 76, 52-57. [CrossRef]

107. Dufford, A.J.; Bianco, H.; Kim, P. Socioeconomic disadvantage, brain morphometry, and attentional bias to threat in middle childhood. Cogn. Affect. Behav. Neurosci. 2019, 19, 309-326. [CrossRef] [PubMed]

108. Noble, K.G.; Houston, S.M.; Brito, N.H.; Bartsch, H.; Kan, E.; Kuperman, J.M.; Akshoomoff, N.; Amaral, D.G.; Bloss, C.S.; Libiger, O.; et al. Family income, parental education and brain structure in children and adolescents. Nat. Neurosci. 2015, 18,773-778. [CrossRef] [PubMed]

109. Whittle, S.; Dennison, M.; Vijayakumar, N.; Simmons, J.G.; Yücel, M.; Lubman, D.I.; Pantelis, C.; Allen, N.B. Childhood maltreatment and psychopathology affect brain development during adolescence. J. Am. Acad. Child Adolesc. Psychiatry 2013, 52, 940-952. [CrossRef]

110. Schore, A.N. Attachment and the regulation of the right brain. Attach. Hum. Dev. 2000, 2, 23-47. [CrossRef] [PubMed]

111. Teicher, M.H.; Andersen, S.L.; Polcari, A.; Anderson, C.M.; Navalta, C.P.; Kim, D.M. The neurobiological consequences of early stress and childhood maltreatment. Neurosci. Biobehav. Rev. 2003, 27, 33-44. [CrossRef] 
112. Paul, R.; Henry, L.; Grieve, S.M.; Guilmette, T.J.; Niaura, R.; Bryant, R.; Bruce, S.; Williams, L.M.; Richard, C.C.; Cohen, R.A.; et al. The relationship between early life stress and microstructural integrity of the corpus callosum in a non-clinical population. Neuropsychiatr. Dis. Treat. 2008, 4, 193. [CrossRef]

113. De Bellis, M.D.; Zisk, A. The biological effects of childhood trauma. Child Adolesc. Psychiatr. Clin. 2014, 23, 185-222. [CrossRef]

114. Teicher, M.H.; Tomoda, A.; Andersen, S.L. Neurobiological consequences of early stress and childhood maltreatment: Are results from human and animal studies comparable? Ann. N. Y. Acad. Sci. 2006, 1071, 313-323. [CrossRef]

115. Guillemin, C.; Provençal, N.; Suderman, M.; Côté, S.M.; Vitaro, F.; Hallett, M.; Tremblay, R.E.; Szyf, M. DNA methylation signature of childhood chronic physical aggression in T cells of both men and women. PLoS ONE 2014, 9, e86822. [CrossRef]

116. Szyf, M. DNA methylation, the early-life social environment and behavioral disorders. J. Neurodev. Disord. 2011, 3, 238-249. [CrossRef]

117. Caspi, A.; McClay, J.; Moffitt, T.E.; Mill, J.; Martin, J.; Craig, I.W.; Poulton, R. Role of genotype in the cycle of violence in maltreated children. Science 2002, 297, 851-854. [CrossRef] [PubMed]

118. Jackson, D.B.; Beaver, K.M. The influence of nutritional factors on verbal deficits and psychopathic personality traits: Evidence of the moderating role of the MAOA genotype. Int. J. Environ. Res. Public Health 2015, 12, 15739-15755. [CrossRef] [PubMed]

119. Kraaijenvanger, E.J.; He, Y.; Spencer, H.; Smith, A.K.; Bos, P.A.; Boks, M.P. Epigenetic variability in the human oxytocin receptor (OXTR) gene: A possible pathway from early life experiences to psychopathologies. Neurosci. Biobehav. Rev. 2019, 96, 127-142. [CrossRef] [PubMed]

120. Palumbo, S.; Mariotti, V.; Iofrida, C.; Pellegrini, S. Genes and aggressive behavior: Epigenetic mechanisms underlying individual susceptibility to aversive environments. Front. Behav. Neurosci. 2018, $12,117$. [CrossRef]

121. Waltes, R.; Chiocchetti, A.G.; Freitag, C.M. The neurobiological basis of human aggression: A review on genetic and epigenetic mechanisms. Am. J. Med Genet. Part B Neuropsychiatr. Genet. 2016, 171, 650-675. [CrossRef]

122. Svrakic, D.M.; Cloninger, R.C. Epigenetic perspective on behaviour development, personality, and personality disorders. Psychiatr. Danub. 2010, 22, 153-166.

123. Cecil, C.A.; Walton, E.; Jaffee, S.R.; O'Connor, T.; Maughan, B.; Relton, C.L.; Smith, R.G.; McArdle, W.; Gaunt, T.R.; Ouellet-Morin, I.; et al. Neonatal DNA methylation and early-onset conduct problems: A genome-wide, prospective study. Dev. Psychopathol. 2018, 30, 383-397. [CrossRef]

124. Reuben, A.; Sugden, K.; Arseneault, L.; Corcoran, D.L.; Danese, A.; Fisher, H.L.; Moffitt, T.E.; Newbury, J.B.; Odgers, C.; Rasmussen, L.J. Association of Neighborhood Disadvantage in Childhood With DNA Methylation in Young Adulthood. JAMA Netw. Open 2020, 3, e206095. [CrossRef]

125. Hannon, E.; Knox, O.; Sugden, K.; Burrage, J.; Wong, C.C.; Belsky, D.W.; Corcoran, D.L.; Arseneault, L.; Moffitt, T.E.; Caspi, A.; et al. Characterizing genetic and environmental influences on variable DNA methylation using monozygotic and dizygotic twins. PLoS Genet. 2018, 14, e1007544. [CrossRef]

126. Moffitt, T.E.; Beckley, A. Abandon Twin Research-Embrace Epigenetic Research: Premature Advice for Criminologists. Criminology 2015, 53, 121. [CrossRef]

127. Baskin-Sommers, A.R. Dissecting antisocial behavior: The impact of neural, genetic, and environmental factors. Clin. Psychol. Sci. 2016, 4, 500-510. [CrossRef]

128. Burt, S.A.; McGue, M.; Iacono, W.G. Environmental contributions to the stability of antisocial behavior over time: Are they shared or non-shared? J. Abnorm. Child Psychol. 2010, 38, 327-337. [CrossRef] [PubMed]

129. Davis, S.W.; Cabeza, R. Cross-hemispheric collaboration and segregation associated with task difficulty as revealed by structural and functional connectivity. J. Neurosci. 2015, 35, 8191-8200. [CrossRef] [PubMed]

130. Stephan, K.E.; Fink, G.R.; Marshall, J.C. Mechanisms of hemispheric specialization: Insights from analyses of connectivity. Neuropsychologia 2007, 45, 209-228. [CrossRef] [PubMed]

131. Dolcos, F.; Katsumi, Y.; Moore, M.; Berggren, N.; de Gelder, B.; Derakshan, N.; Hamm, A.O.; Koster, E.H.; Ladouceur, C.D.; Okon-Singer, H.; et al. Neural correlates of emotion-attention interactions: From perception, learning, and memory to social cognition, individual differences, and training interventions. Neurosci. Biobehav. Rev. 2020, 108, 559-601. [CrossRef] 
132. Song, S.; Zilverstand, A.; Song, H.; Uquillas, F.D.O.; Wang, Y.; Xie, C.; Cheng, L.; Zou, Z. The influence of emotional interference on cognitive control: A meta-analysis of neuroimaging studies using the emotional Stroop task. Sci. Rep. 2017, 7, 1-9. [CrossRef] [PubMed]

133. Weissman, D.H.; Banich, M.T. The cerebral hemispheres cooperate to perform complex but not simple tasks. Neuropsychology 2000, 14, 41. [CrossRef]

134. Nee, D.E.; Wager, T.D.; Jonides, J. Interference resolution: Insights from a meta-analysis of neuroimaging tasks. Cogn. Affect. Behav. Neurosci. 2007, 7, 1-17. [CrossRef]

135. Steinbeis, N.; Bernhardt, B.C.; Singer, T. Impulse control and underlying functions of the left DLPFC mediate age-related and age-independent individual differences in strategic social behavior. Neuron 2012, 73, 1040-1051. [CrossRef]

136. Rolls, E.T. The orbitofrontal cortex and emotion in health and disease, including depression. Neuropsychologia 2019, 128, 14-43. [CrossRef]

137. Wang, M.; Chen, Z.; Zhang, S.; Xu, T.; Zhang, R.; Suo, T.; Feng, T. High Self-Control Reduces Risk Preference: The Role of Connectivity between Right Orbitofrontal Cortex and Right Anterior Cingulate Cortex. Front. Neurosci. 2019, 13, 194. [CrossRef] [PubMed]

138. Kosson, D.S. Divided visual attention in psychopathic and nonpsychopathic offenders. Personal. Individ. Differ. 1998, 24, 373-391. [CrossRef]

139. Suchy, Y.; Kosson, D.S. State-dependent executive deficits among psychopathic offenders. J. Int. Neuropsychol. Soc. JINS 2005, 11, 311. [CrossRef] [PubMed]

140. Kosson, D.S.; Miller, S.K.; Byrnes, K.A.; Leveroni, C.L. Testing neuropsychological hypotheses for cognitive deficits in psychopathic criminals: A study of global-local processing. J. Int. Neuropsychol. Soc. 2007, 13, 267. [CrossRef]

141. Bernstein, A.; Newman, J.P.; Wallace, J.F.; Luh, K.E. Left-hemisphere activation and deficient response modulation in psychopaths. Psychol. Sci. 2000, 11, 414-417. [CrossRef]

142. Simmonite, M.; Harenski, C.L.; Koenigs, M.R.; Kiehl, K.A.; Kosson, D.S. Testing the left hemisphere activation hypothesis in psychopathic offenders using the Stroop task. Personal. Individ. Differ. 2018, 135, 182-187. [CrossRef]

143. Raine, A. Biosocial studies of antisocial and violent behavior in children and adults: A review. J. Abnorm. Child Psychol. 2002, 30, 311-326. [CrossRef]

144. Glenn, A.L.; McCauley, K.E. How biosocial research can improve interventions for antisocial behavior. J. Contemp. Crim. Justice 2019, 35, 103-119. [CrossRef]

145. Van Goozen, S.H.; Fairchild, G. How can the study of biological processes help design new interventions for children with severe antisocial behavior? Dev. Psychopathol. 2008, 20, 941-973. [CrossRef]

146. Buck, K.A.; Dix, T. Parenting and naturally occurring declines in the antisocial behavior of children and adolescents: A process model. J. Fam. Theory Rev. 2014, 6, 257-277. [CrossRef]

147. Wesseldijk, L.W.; Bartels, M.; Vink, J.M.; van Beijsterveldt, C.E.; Ligthart, L.; Boomsma, D.I.; Middeldorp, C.M. Genetic and environmental influences on conduct and antisocial personality problems in childhood, adolescence, and adulthood. Eur. Child Adolesc. Psychiatry 2018, 27, 1123-1132. [CrossRef] [PubMed]

148. Cicerone, K.D.; Dahlberg, C.; Malec, J.F.; Langenbahn, D.M.; Felicetti, T.; Kneipp, S.; Ellmo, W.; Kalmar, K.; Giacino, J.T.; Harley, J.P.; et al. Evidence-based cognitive rehabilitation: Updated review of the literature from 1998 through 2002. Arch. Phys. Med. Rehabil. 2005, 86, 1681-1692. [CrossRef] [PubMed]

149. Stiles, J.; Brown, T.T.; Haist, F.; Jernigan, T.L. Brain and Cognitive Development. In Handbook of Child Psychology and Developmental Science, 7th ed.; Richard, M.L., Ed.; John Wiley \& Sons, Inc.: New York, NY, USA, 2015; pp. 1-54.

150. Wade, M.; Prime, H.; Jenkins, J.M.; Yeates, K.O.; Williams, T.; Lee, K. On the relation between theory of mind and executive functioning: A developmental cognitive neuroscience perspective. Psychon. Bull. Rev. 2018, 25, 2119-2140. [CrossRef] [PubMed]

151. Wikström, P.O.H.; Treiber, K. Social disadvantage and crime: A criminological puzzle. Am. Behav. Sci. 2016, 60, 1232-1259. [CrossRef] [PubMed]

152. Pfundmair, M.; Graupmann, V.; Frey, D.; Aydin, N. The different behavioral intentions of collectivists and individualists in response to social exclusion. Personal. Soc. Psychol. Bull. 2015, 41, 363-378. [CrossRef] [PubMed] 
153. Way, B.M.; Lieberman, M.D. Is there a genetic contribution to cultural differences? Collectivism, individualism and genetic markers of social sensitivity. Soc. Cogn. Affect. Neurosci. 2010, 5, 203-211. [CrossRef]

154. Fallon, J.H. Neuroanatomical backgrown to understanding the brain of the young psychopath. Ohio State J. Crim. Law 2006, 3, 341-368.

155. Wertz, J.; Caspi, A.; Belsky, D.W.; Beckley, A.L.; Arseneault, L.; Barnes, J.C.; Corcoran, D.L.; Hogan, S.; Houts, R.M.; Morgan, N.; et al. Genetics and crime: Integrating new genomic discoveries into psychological research about antisocial behavior. Psychol. Sci. 2018, 29, 791-803. [CrossRef]

Publisher's Note: MDPI stays neutral with regard to jurisdictional claims in published maps and institutional affiliations.

(C) 2020 by the author. Licensee MDPI, Basel, Switzerland. This article is an open access article distributed under the terms and conditions of the Creative Commons Attribution (CC BY) license (http://creativecommons.org/licenses/by/4.0/). 